\title{
Fair Trade and McKesson \& Robbins
}

\section{Edward S. Herman*}

"Fair trade" is suffering from serious and growing difficulties, and recent economic and judicial developments have been sufficiently threatening to provoke speculation as to the imminence of a complete breakdown of this system of resale price control. ${ }^{1}$ The considerable political influence still wielded by the organized advocates of fair trade and its well entrenched position in certain fields ${ }^{2}$ make such an eventuality quite unlikely within the near future. Nevertheless, in a number of fair trade strongholds, such as electrical appliances and jewelry, traditional wholesale and retail markups have been found to be virtually impossible to maintain in the face of prevalent consumer attitudes, competitive forces at work in the distributive sector, and manufacturer interest in expanding sales volume. As one author has recently observed: "The growth of discount louses suggests that however reasonable margins up to 40 per cent were at one time, they are too high now. The hungry post-war market, aided by fair trade laws and manufacturers' resale price maintenance policies, may have served to conceal this fact."

The severity of recent pressures on distributive margims is derived in part from widespread consumer aggressiveness in soliciting price concessions. "This is "natural" behavior in a highly competitive society in which sellers exert ever increasing pressure to convince consumers that prestige can be maintained only if last year's "obsolete" durable good is traded in for the latest inodel. Many such durable goods have become middle class "necessities" in the postwar period, while at the same time many persons within this class "have felt the squeeze of higher taxes on incomes that in-

* Assistant Professor of Economics, Pennsylvania State University.

${ }_{1}$ See, e.g., Fair Trade, Elec. Merchandising, June 1955, p. 220; Advertising Attacks List Prices, Tide, July 27, 1956, p.32 ; Fair Trade Faces Showdown, Nation's Bus., March 1955, pp. 34-35.

$2 E . g .$, drug products.

3 Gilchrist, The Discount House, 17 J. Markering 267, 271 (1953); see Alexander \& Hill, What to Do About the Discount House, HaRv. Bus. Rev., Jan.-Feb. 1955, pp. 58-59. The recent downward adjustment of dealer margins on its fair-traded appliances by General Electric Company was an explicit attenipt to reduce price-cutting by diminishing the incentives implicit in the previous "unrealistic" pricing policy. See GE's Move: Portent for Dealers, Bus. Week, Jan. 7, 1956, p. 94.

4 An important refiection of the intensity of consumer interest in the possibilities of discount buying has been the rapid growth in recent years of buyers' leagues and clubs, organized to solicit discounts for local employee groups (and occasionally a broader clientele). See HorIANDER, DISCOUNT RETAKING 36-38 (unpublished thesis in University of Pennsylvania Library 1954). See also Adventures in Shopping-The Discount Houses, Sales Management, July 1 , 1954, p. 42; Weiss, The Off-List Revolution, Elec. Merchandising, Oct. 1954, pp. 88, 92. 
creased less rapidly than those of other groups, and many of them turned to the discount house as a neans of maintaining their standard of living." With some 1.7 million retail firms widely dispersed throughout the system; with retail selling frequently engaged in by wholesalers, nranufacturers, and building contractors; with retailers themselves showing increased willingness to move outside of traditional merchandising lines to take advantage of high margins on fast-moving items formerly sold elsewhere; and with new and old enterprises and distributive units striving to adapt to changing patterns of consumer wants, the price-conscious buyer is often able to choose between effectively competing alternatives. The prevalence of a "buyers' market" in many markets for durable goods since the Korean war has tended to reinforce these structural conditions conducive to competitive behavior. $^{6}$

Frequently, manufacturer interests and policies have been inconsistent with the requirenents of effective retail price control. Under the pressures of excess capacity and vigorous sales efforts by competitors, many manufacturers seeking to increase sales volume have sought out and sup. plied well known discount houses and buyers' clubs with fair-traded nierchandise. Numerous producers have imposed quotas on wholesalers and retailers which have virtually forced them into price-cutting and disposing of excessive inventories through discounters; other producers have induced dealers to overstock in order to take advantage of generous quantity discounts. Rapid unloading of inventories at discount prices has also been encouraged by manufacturer efforts to render old stocks obsolete by rapid product variation. Moreover, the pre-selling, warranty, and direct service policies of producers have tended to loosen the bond between retailer and consumer and to induce buyer shopping for price concessions. ${ }^{7}$

Manufacturer efforts to enforce fair trade prices have been increasingly inadequate, and the iniquity of fair-trading producers who refuse to engage in serious enforcement has generated considerable eloquence and indignation at fair trade gatherings in recent years. ${ }^{8}$ Many producers, desirous of

\footnotetext{
5 Alexander \& Hill, What to Do About the Discount House, HaRv. Bus. REv., Jan.-Feb. 1955, p. 57; Silberman, Retailing: It's a New Ball Game, Fortune, Aug. 1955, pp. 78-79.

${ }^{6}$ See Lebow, Price Competition in 1955, 31 J. Retaring 6, 9 (1955); Silberman, stipra note 5 .

7 See Alexander \& Hill, What to Do About the Discount House, Harv, Bus. Rev, Jan,Feb. 1955, pp. 53, 57-58; Horcander, Discount Retaming 138-43 (unpublished thesis in University of Pennsylvania Library 1954).

8 See, e.g., 'Fair Trade' Evasion by Producer Scored, New York Times, Nov. 10, 1955, p. 57, col. 6; Law Urged to End Fair Trade Abuse, New York Times, Dec. 7, 1954, p. 51, col. 4; Fair Trade Fight Far from Ended, New York Times, Nov. 21, 1954, § 3, p. 1, col.3. Inadequate enforcement by manufacturers has provoked spokesmen for fair trade to urge dealers to hoycott non-cooperating producers and to press for passage of a "fair-play" amendment to the McGuire Act that would permit dealers to seek injunctions and file daniage suits against manufacturers who supply fair-traded merchandise to discount retailers. See S. 2055, 84th
} 
taking advantage of the sales possibilities of discount outlets, but fearful of dealer retaliation, have engaged in token enforcement calculated to persuade small independents of their continued good faith. ${ }^{9}$ Those manufacturers who have made serious efforts to police fair trade have encountered considerable difficulty in eliminating discount selling even where enforcement expenditures have been substantial. ${ }^{10}$ Very few manufacturers have officially abandoned fair trade, but de facto abandonment has increased markedly in recent years. ${ }^{11}$

Since 1948 the tide of judicial opinion has turned against fair trade. ${ }^{12}$ At the end of that year fair trade was operative in 45 states; by August 1, 1956, unfavorable court decisions had reduced the number of jurisdictions

Cong., 1st Sess. (1955) ; H.R. 7674, 84th Cong., 1st Sess. (1955). Deficient enforcement impelled one retailer group (jewelers) to appeal to the Federal Trade Commission to enforce state fair trade laws against price-cutters. In refusing to comply with this request the Commission suggested that among the possible avenues of self-help available to retailers was price competition, a busmess method which is neither "morally reprehensible" nor illegal where enforcement is inadequate. See 1 CCH TRADE REg. REP. I 3020.90.

It might be pointed out that the Federal Trade Commission has demonstrated its lack of sympathy with fair trade on numerous other occasions, as in its massive REPORT ON RESAIE Price Matnienance (1945); in the hearings which preceded the passage of the McGuire Act, Hearings Before the Antitrust Subcommittee of the House Committee on the Judiciary, 82d Cong., 2d Sess., ser. 12, at 75-107 (1952); and in its frequent assaults on collusive efforts to implement fair trade. See 1 CCH TrAdE REg. REP. I 3020.54. Chairman Howrey's 1954 statement to the Senate District Committee that the Commission did not oppose the enactment of a fair trade bill for the District of Columbia, and did not believe that District goods should bo subject to rules different from those of neighboring states, represents a break in a long-standing and consistent pattern of opposition to fair trade. See Derenberg, Trade Regulation, 30 N.Y.U. L. Rev. 345, 359 (1955). The Department of Justice has evinced a similar antagonisin to fair trade in recent years. In addition to consistently strong statements of opposition in public hearings (Hearings, supre at 18-59; Hearings Before the Antitrust Subcommittee of the House Committee on the Judiciary, 84th Cong., 1st Sess., ser. 3, pt. 1, at 234-42 (1955)), exceptional publicity was given the recommendation of the Attorney General's National Committee to Study the Antitrust Laws that the fair trade laws be repealed; and the Antitrust Division has kept an unusually sharp eye pealed for collusive activities connected with resale price fixing.

8 Holrander, Discount Retairing 155-59 (unpublished thesis in University of Pennsylvania Library 1954).

${ }^{10}$ Thus, a spokesman for the Sheaffer Pen Company observed that despite a two-year campaign of tracking down and carrying out legal proceedings against price cutters, and repurchasing pens from discount houses, at a cost in excess of $\$ 1$ million, "we fonnd that Sheaffer merchandise still found its way into discount houses. Obviously, sone retail outlets were diverting their stocks to the houses. We found that we couldn't enforce our program vigorousiy enough so that small retailers were in a position to compete with the discount houses and other merchandisers." Shaeffer Says It Dropped Fair Trade So It Could Get into Discount Houses, Advertising Age, December 12, 1955, p. 1, 8. See also Westinghouse Off Fair Trade, Bus. Week, Sept. 1955, p. 31.

11 See authorities cited at notes 1 and 9 supra.

12 The absolute number of decisions favorable to fair trade remains far in excess of unfavorable decisions. See Derenberg, Trade Regulation, 30 N.Y.U.L. Rev. 345, 354 (1955); Derenberg, Trade Regulation, 31 N.Y.U.L. REv. 255, 267-69 (1956). However, the judicial tide has turned in the sense that the number of unfavorable decisions destructive of the foundations of fair trade has increased significantly. 
in which fair trade could operate effectively to 32. In the states of Arkansas, Colorado, Florida, Georgia, Kentucky, Louisiana, Michigan, and Oregon, the non-signers clause has been declared unconstitutional..$^{13}$ In Utah, South Carolina, Indiana, and Nebraska the entire fair trade act has been invalidated as unconstitutional; ${ }^{14}$ and in Virginia the fair trade act has been declared to be inoperative due to its inconsistency with the basic antitrust laws of that state. ${ }^{15}$ These states may not be irretrievably lost from the fair trade fold, but the trend since 1948 suggests that a continued exodus may inore than offset the number of returnees. Meanwhile the area of operation of fair trade has been directly reduced, and the possibilities of further disruption of fair trade as a result of discount selling through the mails between non-fair trade and fair trade jurisdictions have been increased. ${ }^{10}$

In 1950 a severe blow was dealt fair trade in Sunbeam Corp. v. Wentling, ${ }^{17}$ in which the fair trade act of Pennsylvania was held to be inapplicable to sales originating in Pennsylvania but sold to consumers residing outside that state. Still more devastating was the 1951 Supreme Court ruling in Schwegmann Bros. v. Calvert Distillers Corp..$^{18}$ that the MillerTydings Act ${ }^{19}$ does not extend immunity from the federal antitrust laws to the inaintenance of the resale prices of non-signers. The deficiencies in the fair trade arsenal revealed or created by these decisions were remedied shortly thereafter by the passage of the McGuire Act. ${ }^{20}$ However, in the

13 Union Carbide and Carbon Corp. v. White River Distributors, Inc., 224 Ark. 558, 275 S.W.2d 455 (1955); Olin Mathieson v. Francis, ........ Colo. ........, 301 P.2d 139 (1956); Miles Laboratories v. Eckerd, 73 So. 2d 680 (Fla. 1954); Cox v. General Elec. Co., 211 Ga. 286, 85 S.E.2d 514 (1955); General Elec. Co. v. American Buyers Cooperative, Inc., CCH TrADE Reg. Rep. (1956 Trade Cas.) II 68341 (Ky., May 2, 1956); Dr. G. H. Tichenor Antiseptic Co. v. Schwegmann Bros. Giant Super Markets, ........ La. ........, 90 So. 2d 343 (1956); Shakespeare Co. v. Lippman's Tool Shop Sporting Goods Co., 334 Mich. 109, 54 N.W.2d 268 (1952); General Elec. Co. v. Wahle, ........ Ore. ........., 296 P.2d 635 (1956). The "non-signers clause" is that part of each state fair trade law which obligates notified distributors to adhere to the terms of a fair trade contract entered into by a manufacturer and a single distributor.

14 General Elec. Co. v. Thrifty Sales, Inc., CCH Trade Reg. REp. (1956 Trade Cas.) I 68482 (Utah Sup. Ct. Sept. 22, 1956); Rogers-Kent, Inc. v. Westinghouse Elec. Corp., 1955 Trade Cas. I 68084 (S.C. County Ct.) ; Bargain Barn, Inc. v. Arvin Industries, Inc., 1955 Trade Cas. I 68074 (Ind. Super. Ct.); McGraw Elec. Co. v. Lewis \& Smith Drug Co., 159 Neb. 703, 68 N.W.2d 608 (1955).

15 Benrus Watch Co. v. Kirsch, 198 Va. 94, 92 S.E.2d 384 (1956).

16 Several recent rulings have held that state fair trade acts do not provide the extraterritorial powers necessary to prevent the advertising and selling of fair-traded goods below contract prices in fair trade states by vendors in non-fair trade jurisdictions. See Bissell Carpet Sweeper Co. v. Masters Mail Order Co., 140 F. Supp. 165 (D. Md. 1956); Revere Camera Co. v. Masters Mail Order Co., 128 F. Supp. 457 (D. Md. 1955).

17185 F.2d 903 (3rd Cir. 1950).

18341 U.S. 384 (1951).

1950 STAT. 693 (1937), 15 U.S.C. 81 (1952).

2066 STAT. 631, 15 U.S.C. \& 45 (1952). 
recent case of United States $v$. McKesson \& Robbins, Inc. ${ }^{21}$ the Supreme Court dealt a new blow of major proportions to fair trade. We turn now to an analysis of this important decision.

\section{THE MCKESSON \& ROBBINS CASE}

In a six to three opinion written by Chief Justice Warren, the Supreme Court held that a manufacturer-wholesaler could not conclude fair trade agreements with independent wholesalers who compete with the wholesale division of the vertically integrated concern on the ground that both the Miller-Tydings and McGuire Acts specifically exclude from their antitrust exemptions all agreements "between wholesalers" or "between persons, firms, or corporations in competition with each other."22 This is a serious threat to continued effective operation of fair trade since it casts "substantial doubt on the legality of fair trade for all those manufacturers who themselves distribute a part of their product at wholesale or retail." ${ }^{23} \mathbf{A}$ recent survey ${ }^{24}$ of the distribution channels of fair-trading manufacturers disclosed that of 322 manufacturers surveyed, 253 (78.6 per cent) not only sell their fair-traded merchandise to independent wholesalers but engage in wholesaling themselves by selling to retailers either directly or through wholly-owned subsidiaries. One hundred and eight ( 33.5 percent) of the 322 manufacturers were selling fair-traded products to independent retailers while at the same time engaging in retail selling to consumers directly or through wholly-owned subsidiaries. Unfortunately, this survey does not provide information regarding the extent to which these mixed channels are used in the same marketing area; frequently, several distributive channels are utilized by one manufacturer because of differing conditions in the various markets. Nevertheless, the available evidence suggests that the $M c K e s s o n$ \& Robbins decision will compel a substantial number of fairtradimg nlanufacturers to make an all-or-nothing choice within each market area between fair-trading and maintaining a vertically integrated organiza-

21351 U.S. 305 (1956).

22 The quoted language is found in both the Miller-Tydings and McGuire Acts. The complete proviso from which it is taken proceeds as follows in the McGuire Act: "Nothing contained in paragraph (2) of this subsection shall make lawful contracts or agreements providing for the establishment or maintenance of minimum or stipulated resale prices on any commodity referred to in paragraph (2) of this subsection, between manufacturers, or between producers, or between wholesalers, or between brokers, or between factors, retailers, or between persons, firms, or corporations in competition with each other." Federal Trade Commission Act $\S 5$ (a) (5), as amended, 66 STAT. $631,632,15$ U.S.C. $\$ 45$ (1952).

23 Rothwell, Fair Trade at the Crossroads, Fair Trade Trends, May 24, 1956, p. 1.

24 Survey of fair-trading manufacturers, compiled for the American Fair Trade Council, Inc. (Dec. 9, 1953, mimeographed). See also Marketing Channeis 69 (Clewett ed. 1955); Weston, Resale Price Maintenance and Market Integration: Fair Trade or Foul Play?, 22 Gro. WASH. L. REv. 658, 675-76 (1954). 
tion. It is a moot question as to how many manufacturers are prepared to reorganize their methods of distribution in order to preserve a technique of resale price control which has become increasingly difficult to use effectively. ${ }^{25}$

The McKesson \& Robbins decision represents the culmination of a series of proceedings which began in 1951 challenging fair trade pricing by vertically integrated concerns. ${ }^{26}$ The possibility of such a challenge has always been implicit in the broad condemnation of horizontal combinations in the federal fair trade laws, ${ }^{27}$ but prior to 1951 no suggestion of impropriety in the use of fair trade by vertically integrated firms had been hinted at by the Federal Trade Commission or the Department of Justice. After somewhat checkered careers the two Federal Trade Commission proceedings carried out along these lines were dismissed by the Commission as without substance. ${ }^{28}$ The leading private suit emphasizing the issue of the legitimacy of fair-trading by vertically integrated enterprises yielded the same result. ${ }^{29}$ In $M c K e s s o n$ \& Robbins the Government converted an apparently repudiated mode of attack into a major threat to the viability of fair trade.

The proceeding against McKesson and Robbins was a civil action ${ }^{80}$ for injunctive relief brought by the Government in 1952 under section 4 of the Sherman Act. ${ }^{31}$ The complaint charged that the company's fair trade agreements with independent wholesalers with whom it was in competition constituted illegal price fixing in violation of section 1 of the act. A government motion for a summary judgment was denied, ${ }^{82}$ whereupon the case proceeded to trial before another district judge. The per se illegality of fair trade pricing by a producer-wholesaler, argued on the motion for summary judgment, was again denied, the evidence of any "additional restraint"

25 It may also be asked whether a manufacturer selling on consignment or through exclusive agents would violate the law by simultaneously selling under fair trade contracts within the same market area. Since the manufacturer retains an ownership interest in goods which are consigned or sold through exclusive agents, it may be held that such manufacturer "competes" through his agents with independent distributors and retailers and is therefore precluded from entering into price contracts with the latter.

26 In the Matter of Doubleday and Company, Inc., F.T.C. Docket No. 5897, June 21, 1951 ; United States v. McKesson \& Robbins, Inc., Civil No. 76-50, S.D.N.Y., May 27, 1952, CCH Trade Reg. ReP. If 66,033; In the Matter of Eastman Kodak Co., F.T.C. Docket No. 6040, Sept. 8, 1952.

27 See note 22 supra.

28 Eastman Kodak Co., CCH Trade Reg. Rep. 125291 (FTC 1955) ; Doubleday and Co., CCH TRADE REg. REP. I 25634 (FTC 1955).

28 Eastman Kodak Co. v. Schwartz, 133 N.Y.S.2d 908 (Sup. Ct. 1954).

80 United States v. McKesson \& Robbins, Inc., Civil No. 76-50, S.D.N.Y., May 27, 1952, CCH Trade Reg. Rep. \66033.

3126 STAT. 209 (1890), 15 U.S.C. $\$ 4$ (1952).

32 United States v. McKesson \& Robbins, Inc, 122 F. Supp. 333 (S.D.N.Y. 1954). 
within the meaning of the test laid down by the first district judge was deemed to be inadequate, and a dismissal was ordered. ${ }^{33}$ The Government took a direct appeal to the Supreme Court under the Expediting Act. ${ }^{34}$

In reversing the lower court the Supreme Court called attention to the following facts: McKesson and Robbins is the largest drug wholesaler in the United States, with 74 wholesale divisions located in 35 states, engaged in selling drugstore merchandise to retailers throughout the country. For the fiscal year ending March 31, 1954, sales of all drug products by McKesson and Robbins totaled 338 million dollars. The vast bulk of McKesson's wholesale sales are in products supplied to it by others, but some of its sales are of drugs, pharmaceuticals, cosmetics and toilet products produced in its own manufacturing establishment in Bridgeport, Connecticut. ${ }^{35}$ Such manufactured products were sold mainly through McKesson's own wholesale divisions, but some were channeled directly to large retailers and independent wholesalers. ${ }^{36}$

Where permitted under state law McKesson and Robbins entered into fair trade agreements with retailers and independent wholesalers. Of 21 independent wholesalers who bought directly from its manufacturing division and with whom McKesson had fair trade agreements, 16 competed with the McKesson wholesale divisions and the remaining 5 competed with its manufacturing division for sales to chain drugstores located in their trading areas. As a resnlt of a 1951 policy decision 73 independent wholesalers who regularly obtained McKesson products from the latter's wholesale divisions entered into fair trade agreements with McKesson and Robbins as a condition for obtaining McKesson and Robbins labeled products. "Each of these independent wholesalers is in direct competition with the McKesson wholesale division from which it buys." ${ }^{.37}$

The legal issue seen by the majority was "a narrow one of statutory interpretation." ${ }^{\prime 38}$ The Government did not challenge the vertical contracts between McKesson and its retail outlets but merely its "price-fixing agreements with independent wholesalers with whom it is in competition." Since the exemptions from the antitrust laws written into the MillerTydings and McGuire Acts explicitly exclude horizontal agreements between businesses in competition with one another, ${ }^{40}$ plain language consid-

33 United States v. McKesson \& Robbins, Inc., 1955 Trade Cas. $\pi 68066$ (S.D.N.Y.).

3432 STAT. 823 (1903), 15 U.S.C. § 28-29 (1952).

35 For the year ending March 31, 1954 sales by McKesson of its manufactured products. aggregated 11 million dollars, about $3.2 \%$ of its total sales for that year.

36351 U.S. at 206-07.

37 Id. at 308.

38 Id. at 309.

39 Ibid.

40 See note 22 supra. 
erations led the Supreme Court majority to the conclusion that McKesson's fair trade contracts fell outside the ambit of these exemptions and within the scope of the "per se" doctrine prohibiting price-fixing.1 In answer to McKesson and Robbins' argument that "in contracting with imdependent wholesalers, it acted solely as a manufacturer selling to buyers rather than as a competitor of these buyers, ${ }^{, 42}$ the Supreme Court said: ${ }^{43}$

But the statutes provide no basis for sanctioning the fiction of McKesson, the country's largest drug wholesaler, acting only as a manufacturer when it concludes "fair trade" agreennents with competing wholesalers. These were agreements "between wholesalers."

Any doubts which might otherwise be raised as to the propriety of considering a manufacturer-wholesaler as a "wholesaler" are dispelled by the last phrase of the proviso in question, which continues the proscription against price-fixing agreements "between persons, firms, or corporations in competition with each other." Congress thus unade as plain as words can make it that, without regard to categories or labels, the crucial inquiry is whether the contracting parties compete with each other. If they do, the Miller-Tydings and McGuire Acts do not pernnit them to fix resale prices.

In a strong dissenting opinion, concurred in by Justices Frankfurter and Burton, Justice Harlan leveled two fundamental criticisms at the majority opinion. He argued first that there are no distinctive economic effects attributable to fair-trading by a vertically integrated manufacturer that are not already implicit in fair trade. ${ }^{44}$ Secondly, he contended that the congressional purpose in preventing horizontal agreements was to maintain inter-brand competition and to prevent the initiation of fair trade agreenients by anyone other than the owner of the brand name: ${ }^{45}$

Interpreting the provisos in the light of these considerations, I conclude that an integrated manufacturer selling its products under fair-trade contracts to independent wholesalers should be deemed to be acting as a "manufacturer" rather than as a "wholesaler." This interpretation [permits] ... . manufacturers to maintain the resale prices of their branded products while preserving competition between brands.

41 "There is no basis for supposing that Congress, in enacting the Miller-Tydings and McGuire Acts, intended any change in the traditional per se doctrine. The District Court was plainly in error in attempting to create a category of agreements which are outside the exemption of these Acts but which should nevertheless be spared from application of the per se rule." 351 U.S. at $310-11$.

42 Id. at 312-13.

43 Ibid.

44 "If we accept the legislative judgment implicit in the Acts that resale price maintenance is necessary and desirable to protect the goodwill attached to a brand name, there is no meaningful distinction between the fair-trade contracts of integrated and non-integrated manufacturers. Certainly the integrated manufacturer bas as strong a claim to protection of his goodwill as a non-integrated manufacturer, and the economic effect of the contracts is the same." Id. at $317-18$.

45 Id. at 319-20. 
As regards the economic effects of fair-trading by a vertically integrated concern, Justice Harlan is on strong ground. The Government contended that the challenged contracts ehminated price competition between the McKesson and Robbins wholesale divisions and independent wholesalers and that the leverage conveyed by its manufacturing operations enabled the manufacturer-wholesaler to dictate prices to independent wholesalers. ${ }^{40}$ The majority opinion, however, dismisses the economic arguments as irrelevant in view of the fact that "Congress has marked the limitations beyond which price-fixing cannot go. We are .. . bound to construe them strictly, since resale price maintenance is a privilege restrictive of a free econony." Nonetheless, it is important to be aware that the fair trade laws sanction horizontal restraints on price conpetition, which are vertically imposed, with respect to a single brand within a general class of products. ${ }^{48}$ It follows that a manufacturer may legally foreclose competition in his brand among distributors by merely fair-trading his product. If a manufacturer sells sone of his products through his own retail or wholesale outlets, it may be formally true that agreenients are in effect "between competitors," but only as regards competition that is already written off and legally extinguishable under the fair trade laws. As Justice Harlan points out: "[I]n either case, all price competition is eliminated, and I ain unable to see what difference it makes between whom the eliminated competition would have existed had it not been eliminated." 49

The Government alleged further that the manufacturer-wholesaler would be able to fix the prices at which independent wholesalers miglnt sell and then proceed to undersell these independent wholesalers by ineans of direct sales to large retailers. ${ }^{50}$ This is a genuine possibility, but it is more a reflection of the power conveyed to the manufacturer by the fair trade laws than a product of a conspiracy to undermine the position of independent distributors. It should also be noted that manufacturers are not compelled to sell through independent wholesalers in the first place; if they choose to do so they are not likely to compete away the business of these distributors although they may maintain special retail preserves for themselves. This argument is also vitiated by the circumstance that while the independent wholesalers are here viewed as potential victims of the challenged conspiracy, the government's complaint alleged these same wholesalers to be co-conspirators with McKesson and Robbins. ${ }^{51}$

46 Id. at 315 n. 20; Complaint, pp. 3-4, United States v. McKesson \& Robbins, Inc., 122 F. Supp. 333 (S.D.N.Y. 1954).

47351 U.S. at 316 (1956).

$\$ 8$ See note 19 supra.

$\$ 9351$ U.S. at 318 (dissent).

$50 \mathrm{Id}$. at $315 \mathrm{n} .20$,

51 Complaint, p. 3, United States v. McKesson \& Robbins, Inc., 122 F. Supp. 333 (S.D. N.Y. 1954). 
Finally, the Government urged that resale price maintenance permits a manufacturer to set fair trade prices and margins sufficiently high to insulate its own wholesalers from the inroads of more efficient operators. ${ }^{\text {t2 }}$ This is true for the products supplied within the vertically integrated firm; ${ }^{63}$ but it is also true that resale price maintenance enables a manufacturer to protect his independent dealers from the encroachment of more efficient competitors..$^{54}$ If a vertically integrated enterprise suffers from inefficient wholesale or retail operations it will tend either to rationalize or dispose of them. Efforts to protect its own inefficient outlets by fixing high distributive margins would run counter to the interest of the integrated firm in large sales volume and wide distribution of its manufactured products. However, where the manufacturer is heavily dependent on multitudes of small, independent, and frequently inefficient dealers, the problem of insulated inefficiency tends to be more acute; since the operations of these distributors are not easily rationalized by the manufacturer, he cannot readily dispense with their services, and the importance of their goodwill frequently enables them to force markups more than ample to cover their excessive costs. ${ }^{65}$ Thus, the protection of inefficient distributors from the inroads of competition from those more efficient must be viewed as one of the purposes and normal consequences of fair trade--one more likely to characterize dis-

52351 U.S. at 315, n. 20. The district court decision has been criticized for failing to recognize that "the crucial issue involved in the use of resale price maintenance by integrated inanufacturers ... . [is] whether the firm has the power and incentive to integrate inefficiently." Note, 64 Yase L.J. 426, 428 n.10 (1954).

53 Note that this would have insulated only between 3 and 5 per cent of McKesson's wholesale business in the early fifties.

54 In this context it is significant that the fair trade laws are largely a product of years of unremitting pressure by organized independent retailers, particularly the National Association of Retail Druggists. Since the primary purpose of these influential advocates of fair trade appears to have been a reduction of price coinpetition and the stabilization of generous dealer inargins, in an important sense the "purpose" of fair trade can be said to be insulation of organized independents in the distributive trades from competitive pressures. See Hearings Before the Antitrust Subcommittee of the House Committee on the Judiciary, 82d Cong., 2d Sess., 436-40 (1952); FTC, Report on Resale Price Maintenance 50-59, 64-66, 131-218 (1945).

55 For many years prior to the general passage of resale price maintenance laws the powerful National Association of Retail Druggists consistently sought a 50 per cent markup on cost on all items regularly sold in drugstores as a primary pohicy objective. Thus, Mr. H. A. Henry, president of the association, stated at a meeting of the executive committee in May 1935 that "the first" point of our 20-point program is $33 \frac{1}{3}$ [on the sale price] on every iteun .... The man who gives the greatest advantage is going to get the cooperation of the retailer." FTC, Report on Resate Price Matntenance 131 (1945). Since the widespread enactment of these laws numerous efforts have been made to obtain this markup objective; these attempts have been implemented frequently by threats, organized boycotts, and promises of special dealer "cooperation." Id, at 131-218. See also the numerous cases involving dealer coercive efforts cited in H.R. ReP. No. 1516, 82d Cong., 2d Sess. 32-33 (1952). 
tribution through independent dealers than through manufacturer-owned outlets.

The majority opinion in McKesson \& Robbins found the legislative history of the proviso prohibiting horizontal combimations to be unedifying "except to show a congressional concern that the prohibition against "horizontal' price fixing be continued." The majority noted a statement on the Senate floor by Senator Hubert Humphrey, who pointed to the existence of widespread vertical integration and stated: ${ }^{57}$

Under the [McGuire] bill, such firms may make resale price-maintenance contracts with both wholesalers and retailers because such contracts are vertical, that is, between sellers and buyers. While in one sense firms in this position function not only as producers but also as wholesalers and retailers, they may still lawfully inake contracts with other wholesalers and retailers, when in making such contracts they act as producers of a trademarked or branded commodity, rather than as wholesalers and retailers entering into forbidden horizontal resale price-maintenance contracts with other wholesalers or other retailers.

However, Chief Justice Warren dismissed this statement as inconclusive on the grounds that Senator Humphrey was not in a position to make an authoritative interpretation of the McGuire Act and becausse ${ }^{58}$

these remarks appear to be confined to the "between wholesalers" and "between retailers" phrases and do not deal with the "corporations in competition" phrase. And even as to the former, it is not at all clear that Senator Humphrey was discussing the situation where actual competition exists between the manufacturer-wholesaler and independent wholesalers.

As regards the substantive part of this criticisun, Senator Humphrey was dealing with the legality of fair-trading by vertically integrated enterprises; since he omitted specific mention of the "corporations in competition" phrase, it is inost reasonable to assume that he did not consider it to require differentiation for the purpose at hand.59 The Senator did not state

56351 U.S. at 315 .

67 Id. at 314, n. 17; 98 Cong. Rec. 8870 (1952).

58351 U.S. at 313 n.17.

50 The majority position is supported to some extent by the very distinction made by Congress between agreements among producers, wholesalers, retailers, etc., and agreements among persons, firms, or corporations in competition. Even before the insertion of the proviso prohibiting horizontal agreements Senator Millard Tydings engaged in the following interesting colloquy with Mr. Edward S. Rogers. "Mr. Rogers: There cannot be any horizontal contracts. They must be vertical from the manufacturer down, not among producers, or among wholesalers and producers. Senator Tydings: Somebody not connected with the same operation? Mr. Rogers: Exactly." Hearings Before a Subcommittee of the Senate Comnittee on the Judiciary, 74th Cong., 2d Sess. 7 (1936).

Senator Tydings' contribution to this exchange was a question rather than a positive statement, and his several direct discussions of horizontal agreements under the Miller-Tydings Act fail to come to grips with the problems posed by vertical integration. See 81 Cong. REc. 7487 (1937) ; 83 CoNG. Rec. App. 441 (1938). Congressional purpose in making the aforementioned distinction remains obscure. 
explicitly that he assumed the existence of "actual competition" between manufacturer-wholesaler and independent wholesaler, but to deny this as an implicit premise is to argue that he was engaged in a pointless discourse regarding the relationships between entirely non-competitive concerns.

It is true that Senator Humphrey was neither in charge of the McGuire bill nor a member of any committee that considered it; nevertheless, he was its most vigorous protagonist on the senate floor, and his exposition on the point in question was unchallenged. Moreover, the Humphrey statement is consistent with fuller congressional discussions ${ }^{60}$ of the nature of the protection afforded by the prohibition of horizontal agreements at the time of the passage of the Miller-Tydings Act. The emphasis in these earlier discussions was on collusion between producers and distributors of different brands of goods as the form of horizontal agreement which this proviso prohibited. Thus, Representative Charles F. McLaughlin, an important participant in deliberations on the Miller-Tydings bill, commented: ${ }^{01}$ "It [the proviso prohibiting horizontal agreements] does not permit contracts between seller and seller of different articles-contracts known as horizontal contracts." In a speech by Representative Joln E. Miller, inserted into the Congressional Record ${ }^{62}$ by Senator Millard Tydings, the prohibition of horizontal combinations is clearly stated to be consistent with intra-brand price fixing: ${ }^{\bullet 3}$

Prices cannot be fixed horizontally. The manufacturers, distributors, and retailers of a certain brand of merchandise may, however, decide at what price they will offer their product to the public. Naturally, this by implication gives the power to determine a margin of profit for each party to the contract, but no such agreement is lawful between manufacturers or distributors or retailers to fix the prices of other commodities of the same class. Any conspiracy or agreement to fix prices on competitive brands is prohibited.

In sum, several fundamental objections may be raised to the decision of the Supreme Court in United States v. McKesson \& Robbins. First, the Miller-Tydings and McGuire Acts constitute a congressional sanction for the elimination of horizontal competition with respect to a particular brand, except, perhaps, where the combination is initiated by parties with no valid interest in the relevant trademark. In McKesson \& Robbins the Supreme Court struck down an arrangement in which there was a valid interest in a trademark and which added substantially nothing to the price fixing already sanctioned by law. Secondly, there is strong evidence that the purpose of

\footnotetext{
${ }^{60}$ See notes 61-63 infra.

6181 CoNG. Rec. 8141 (1937).

6283 Cong. Rec. App. 562 (1938).

B3 Id. at 564 .
} 
Congress in inserting the proviso prohibiting horizontal combinations was to preserve competition between different brands of goods rather than to preserve competition in the sale of a particular brand. The restraint eliminated by the present decision relates to a single brand. Finally, where fair-trading by a vertically integrated concern was discussed explicitly on the floor of Congress, it received congressional approval. Moreover, since vertical integration among fair-trading manufacturers was widely prevalent at the time of passage of the Miller-Tydings and McGuire Acts, it seems reasonable to expect that any congressional intent to deny fair trade to vertically integrated firms would have been expressed rather more explicitly. "There is no indication in the Miller-Tydings Act itself or in its legislative history that Congress intended to ... alter established systems of distribution, in order [that a manufacturer might] ... avail himself of the benefits of the Act." $" 04$

It may be argued that the fair trade laws are, on the whole, detrimental to the well-being of our society, ${ }^{65}$ and that $M c$ Kesson \& Robbins may well prove to be a socially beneficial decision. It is nonetheless true that this important decision reflects an imperfect understanding of the logic of fair trade, and/or a continued unwillingness ${ }^{66}$ on the part of the Supreme Court to adhere to the spirit of congressional policy in this area.

64 Sunbeam Corp. v. Payless Drug Stores, 113 F. Supp, 31, 39 (N.D. Cal. 1953).

65 See Edwards, Matntaintng Compretition 69-72 (1949); FTC, Report on Resate Price Mantienance (1945); Grether, Price Control Under Fatr Trade Legtstatron (1939); Oxenkeldt, Industriat Prictig and Market Practices 422-29 (1951); Stocking and WatkINs, Monopoly and Free Enterprise 322-30 (1951); Herman, A Note on Fair Trade, 65 YAIE L.J. 23 (1955).

${ }^{66}$ Cf. Schwegmann Bros. v. Calvert Distillers Corp., 341 U.S. 384 (1951). 